\title{
Испытание цикория корневого в контрольном ПИтомнике
}

\section{О.М. Вьютнова, Т.Ю. Полянина, И.А. Новикова, В.И. Леунов, А.В. Корнев, P.P. Усманов}

Дана характеристика по результатам испытания в контрольном питомнике нового образца цикория корневого С 0428 (Фаворит) селекции Ростовской ОСЦ - филиал ФГБНУ ФНЦО: среднеспелого, с высокими показателями урожайности и хозяйственно ценными свойствами, корнеплодом усеченной формы, пригодной для механизированной уборки

Ключевые слова: цикорий корневой, урожайность, форма корнеплода.

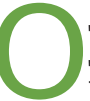
дним из видов с.- х. сырья для пищевой промышленности служит корневой цикорий важный компонент при производстве натурального кофе, чайных и кофейных напитков [1]. Также его используют при производстве спирта и в хлебобулочной промышленности [2].

Ценность его для перерабатывающих и фармацевтических производств определяется содержанием в корнеплодах инулина, фруктозы, интибина и цикореоля $[3,4]$.

Привлекательность культуры корневого цикория для производителей снижена из-за большой трудоемкости ее возделывания и большой доли ручного труда, прежде всего на уборке корнеплодов. Существующие районированные сорта вследствие того, что имеют корнеплоды большой длины, не отвечают требованиям современных промышленных технологий, хотя отличаются высокой степенью адаптивности к условиям НЧЗ РФ, большой урожайностью и отличными химико-технологическими качествами [5]. Современное с.- х. производство крайне остро нуждается в новых сортах корневого цикория, сочетающих в себе высокую урожайность и химико-технологические качества, имеющих форму корнеплода, пригодную для механизированной уборки.

Цель работы - провести испытание перспективных образцов цикория корневого в контрольном питомнике в условиях Ярославской области.

Исследования проводили в 20042018 годах на опытном участке Ростовской ОСЦ - филиал ФГБНУ ФНЦО Ярославской области. Почва опытного участка - дерново-среднеподзолистая среднесуглинистая сла- босмытая, $\mathrm{pH}_{\text {ксl }} 4,70-4,80$, содержание гумуса - среднее $(3,40-3,60)$, содержание подвижного фосфора (7585) и обменного калия - среднее (80-90 мг/кг).

Материалом для исследований служили сорта отечественной и зарубежной селекции - 20 образцов.

Опыт закладывали согласно методике опытного дела [6]. В контрольном питомнике: площадь учет-

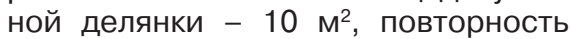
опыта - четырехкратная, схема посе-

Результаты испытания образцов цикория корневого в контрольном питомнике, среднее за 2017-2018 годы

\begin{tabular}{|c|c|c|c|c|c|c|}
\hline \multirow{3}{*}{$\begin{array}{c}\text { Селекцион- } \\
\text { ный номер }\end{array}$} & \multicolumn{4}{|c|}{ Урожайность } & \multirow{3}{*}{$\begin{array}{l}\text { Поражение } \\
\text { корневыми } \\
\text { гнилями, \% }\end{array}$} & \multirow{3}{*}{$\begin{array}{c}\text { Форма } \\
\text { корнеплода }\end{array}$} \\
\hline & \multicolumn{2}{|c|}{ общая } & \multicolumn{2}{|c|}{ стандартная } & & \\
\hline & т/га & $\%$ к St & т/га & $\%$ K St & & \\
\hline C 0401 & 29,0 & 100,0 & 20,7 & 100,7 & 9.4 & цилиндр. \\
\hline C 0404 & 25,7 & 88,6 & 17,6 & 85,6 & 9,9 & веретен. \\
\hline C 0405 & 28,2 & 97,3 & 19,9 & 96,4 & 1,1 & цилиндр. \\
\hline C 0406 & 28,6 & 98,6 & 20,3 & 98,5 & 7,4 & цилиндр. \\
\hline C 0407 & 29,9 & 103,1 & 20,7 & 100,7 & 13,7 & цилиндр. \\
\hline C 0409 & 29,8 & 102,8 & 20,7 & 100,7 & 3,1 & цилиндр. \\
\hline C 0412 & 31,2 & 107,5 & 21,8 & 105,8 & 17,4 & цилиндр. \\
\hline C 0413 & 29,3 & 101,1 & 21,2 & 102,7 & 4,4 & цилиндр. \\
\hline C 0416 & 27,6 & 95,2 & 19,6 & 95,0 & 2,8 & цилиндр. \\
\hline C 0417 & 28,6 & 98,6 & 20,2 & 98,1 & 4,3 & веретен. \\
\hline C 0418 & 30,8 & 106,3 & 21,7 & 105,3 & 7,6 & цилиндр. \\
\hline C 0419 & 28,0 & 96,5 & 19,9 & 95,2 & 4,5 & цилиндр. \\
\hline C 0422 & 30,3 & 104,6 & 21,5 & 104,2 & 6,3 & цилиндр. \\
\hline C 0423 & 29,3 & 101,2 & 20,7 & 100,7 & 4,1 & веретен. \\
\hline C 0426 & 28,8 & 99,1 & 20,7 & 100,7 & 5,4 & цилиндр. \\
\hline C 0427 & 29,3 & 101,2 & 20,9 & 101,4 & 7,6 & цилиндр. \\
\hline C 0428 & 32,8 & 112,8 & 28,9 & 114,6 & 0 & усеч-конич. \\
\hline C 0429 & 28,8 & 99,1 & 20,4 & 99,2 & 4,1 & цилиндр. \\
\hline Петровский (St) & 32,6 & - & 28,4 & - & 5,2 & удлин- конич. \\
\hline $\mathrm{HCP}_{05}$ & 1,9 & & 1,7 & & & \\
\hline
\end{tabular}

ва - 70 см, норма высева - 400 тыс. всхожих семян на 1 га.

Результаты исследований подвергали дисперсионному анализу, разработанному Б.А. Доспеховым [6]. Обработку результатов исследований проводили на ПК в программе Excel 2016.

Метеорологические условия в годы исследований в питомнике исходного материала (20042005 годы - благоприятные для выращивания цикория) и селекционном питомнике (2006-2009, 2013-2016 годы - благоприятные, 2010-2012 годы - неблагоприятные) в контрольном питомнике (20172018 годы) были благоприятные существенно не влияли на урожайность цикория корневого, но не способствовали массовому поражению растений болезнями и вредителями 
В течение этого времени был создан перспективный образец цикория корневого, отвечающий современным требованиям производства, который был получен путем однократного инцухта растения цикория, выделенного из популяции С, с последующим индивидуально-семейственным отбором в селекционном питомнике.

В питомниках селекционного процесса осуществляли последовательные этапы изучения и оценки селекционного материала.

В коллекционном питомнике (2004 год) проводили первоначальное изучение исходного материала с целью выделения образцов, которые в силу необходимых достоинств: раннеспелость, высокая урожайность, усеченная форма корнеплода, устойчивость к болезням и вредителям, включили в дальнейшую работу.

В селекционный питомник включили элитные растения, отобранные из сортопопуляции С непосредственно в питомнике исходного материала. Был проведен инбридинг (2005 год) растения цикория популяции С.

В 2006-2016 годах (селекционный питомник) проводили индивидуально-семейственный отбор, при котором в результате переопыления растений все время в пределах семьи в течение пяти отборов было достигнуто выравнивание, усиление и закрепление нужных признаков.

В контрольном питомнике изучали правильность отбора элитных растений в предыдущих питомниках селекционного процесса. В качестве стандарта использовали сорт Петровский. Оценку селекционных номеров проводили по урожайности, товарности, устойчивости к корневым гнилям, форме корнеплода.

При оценке селекционных номеров наблюдалось сильное варьирование по изучаемым признакам. Присутствие трех типов форм корнеплода (веретеновидной, цилиндрической и конической) в контрольном питомнике объясняется тем, что в результате самоопылений на начальном этапе селекционной работы были расщепления по данному признаку, также вследствие применения индивидуально-семейственного отбора наблюдали незначительную инбредную депрессию (номера С 0417, C 0427, C 0429). Был выделен образец С 0428, превосходящий стандарт по урожайности на $12,8 \%$, по урожайности стандартных корнеплодов на $14,6 \%$, не имеющий корнеп- лодов с признаками гнили и обладающий усеченно-конической формой корнеплода. В Госсортоиспытание в 2019 году этот номер заявлен под названием Фаворит.

Хозяйственно ценные признаки образца Фаворит (С 0428) по сравнению со стандартом (сорт Петровский), соответственно, следующие: общая урожайность - 32,8 т/га (стандарт St- 32,6); товарность $88,1 \%$ (St 87,1\%); форма корнеплода - усеченно-коническая (удлиненно-коническая); степень поражения корневыми гнилями - 0,0\% (St 5,2\%); продолжительность вегетационного периода 115 сут. (St 125); содержание инулина 18,5 мг/100 г сырой массы (St 18,0); форма листовой розетки прямостоячая у обоих образцов; длина корнеплода 19-22 см (St 24-28); число листьев 8-12 (St 10-14).

Основное достоинство образца С 0428 (Фаворит) - то, что он имеет корнеплод усеченно-конической формы, пригодный для механизированной уборки, в том числе на тяжелых по гранулометрическому составу почвах, и глубина погружения в почву составляет до 20 см.

Кроме того, вегетационный период перспективного образца составляет 115 суток, он относится к группе среднеспелых, что является преимуществом в условиях короткого вегетационного периода Нечерноземной зоны РФ.

Предназначен для выращивания в крупно-, мелкотоварных хозяйствах и ЛПХ.

Таким образом, в результате селекционной работы с цикорием корневым создан перспективный образец С 0428 (Фаворит), который удовлетворяет современным требованиям производителей: среднеспелый, имеет короткий корнеплод конической формы, прямостоячую среднеоблиственную листовую розетку, пригодный для механизированной уборки, имеет высокую урожайность, товарность, корневыми гнилями в условиях Ярославской области не поражается.

\section{Библиографический список}

1.Вильчик В.А. Цикорий: рекомендации по выращиванию, уборке, переработке и использованию. Ярославль: Верхне - Волжское книжное изд-во, 1982. $80 \mathrm{c}$.

2.Поляков В.А. и др. Цикорий - перспективное сырье для производства оригинальных напитков // Картофель и овощи. 2018. № 5. С. 20-23.

3.Лузина Е.В. Пищевая ценность цикория // Вопросы питания. 2013. № 2. С. 62-65.

4.Манукян Л.С., Кочикян В.Т., Андреасян Н.А., Афян К.Б., Балаян А.М. Выделение инулина из различного растительного сырья // Биологический журнал
Армении. 2014. № 4 (66). С. 71-75.

5.Вьютнова О.М., Полянина Т.Ю., Леунов В.И. Исходный материал для селекции цикория корневого // Картофель и овощи. 2015. № 9. С. 34-35

6.Доспехов Б.А. Методика полевого опыта (с основами статистической обработки результатов исследований). 5-е изд. доп. и перераб. М.: Агропромиздат, 1985. $351 \mathrm{c}$.

\section{Об авторах}

Вьютнова Ольга Михайловна, канд. с. - х. наук., ст.н.с., Ростовская ОСЦ-филиал ФГБНУ ФНЦО.

E-mail: rossc2010@yandex.ru

Полянина Татьяна Юрьевна, Н.C. Ростовская ОСЦ-филиал ФГБНУ ФНЦО

Новикова Ирина Александровна, н.с., Ростовская ОСЦ-филиал ФГБНУ ФНЦО

Леунов Владимир Иванович, доктор с. - х. наук, профессор, и.о. декана факультета агрономии и биотехнологИИ, ФГБОУ ВО РГАУ-МСХА именИ К.А. Тимирязева.

E-mail: vileunov@mail.ru

Корнев Александр Владимирович, канд. с. - х. наук, н.с. отдела селекции и семеноводства,

ВНИИО-филиал ФГБНУ ФНЦО

Усманов Раиф Рафикович, канд. с. - х. наук, доцент кафедры земледелия и методики опытного дела, ФГБОУ ВО РГАУ-МСХА именИ К.А. Тимирязева.

Testing of chicory in control nursery O.M. Vjutova, PhD, senior research fellow, Rostov OSC - branch of FSBSI FSVC. E-mail: rossc2010@yandex.ru

T.Yu. Polyanina, research fellow, Rostov OSC - branch of FSBSI FSVC

I.A. Novikova, research fellow, Rostov OSC - branch of FSBSI FSVC

V.I. Leunov, DSc, professor, acting dean of the faculty of agronomy and biotechnology, RSAU-MTAA named after K.A. Timiryazev. E-mail:vileunov@mail.ru

A.V. Kornev, PhD, research fellow of

department of breeding and seed growing, ARRIVG-branch of FSBSI FSVC

R.R. Usmanov, PhD, associate professor of department of agriculture and experimental techniques, RSAU-MTAA named after K.A. Timiryazev

Summary. According to the results of testing in the control nursery, a new specimen of root chicory $C 0428$ (Favorit) of selection of the Rostov OSC-branch of FSBSI FSVC: mid-season, with high yield and economically valuable properties, a truncated root crop suitable for mechanized harvesting is given. Keywords: chicory root, yield, form of root crop. 